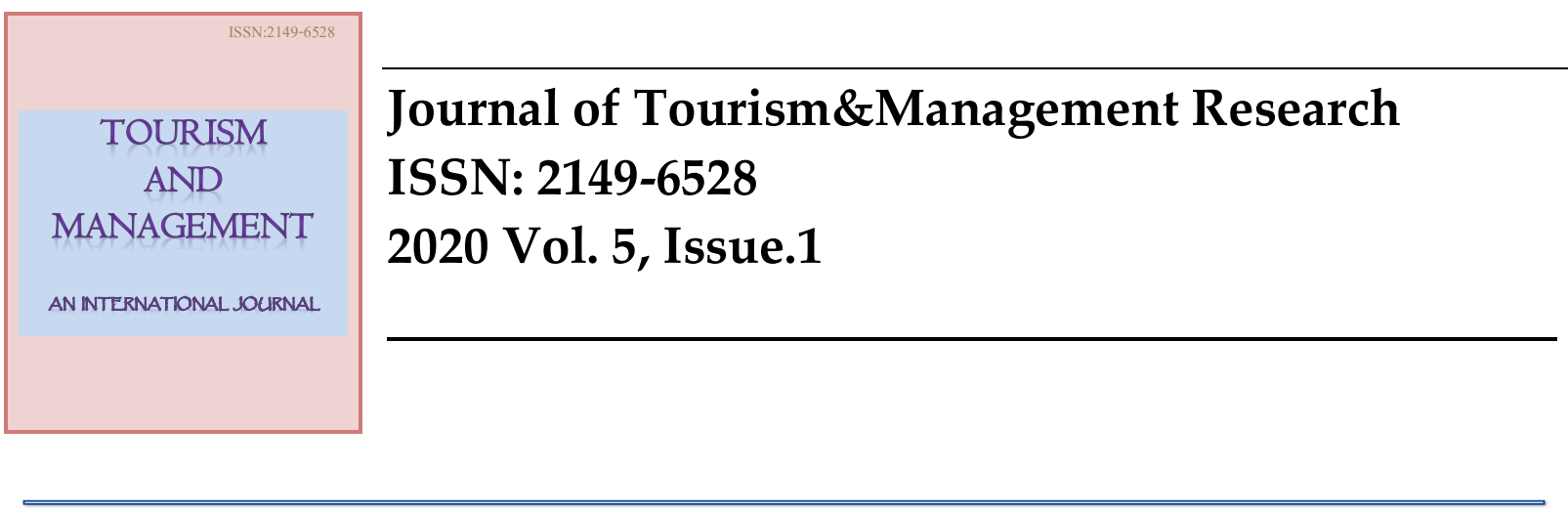

\title{
Moderating Effect of Tourism Business Networks on Tourism Backward Linkage with Local Micro and Small Enterprises in Kisumu County
}

\begin{abstract}
The study aimed to establish whether the effect of physical location and type of tourism enterprises, on extent of tourism backward linkage with local enterprises in Kisumu County was moderated by business networks established by tourism enterprises. Cross section survey of 106 tourism enterprises was conducted and ANOVA was used in the analysis. It was established that the effect of type of tourism enterprise on the local purchase ratio did not vary with the level of business networks developed by tourism businesses, but the effect of physical location of tourism enterprises on local purchase ratio varied with level of networks developed. Also, tourism enterprises with three and more business networks and located in outskirts of Kisumu City and rural areas outperform their counterparts with two and less business networks in creating linkages with local economy. However, tourism enterprises with two and less business networks outperform those with three and more business networks in creating local economic linkages in Kisumu Central Business District (CBD). Therefore, collaborative strategies amongst tourism enterprises in rural areas invigorated local economy more than competition amongst them, but increased competition amongst enterprises in Kisumu CBD as opposed to cooperation improves backward linkage with local economy.
\end{abstract}

Keywords: Tourism business networks, tourism backward linkage, Kisumu city, local purchase ratio

JEL Classifications: L26, L53, Z32

Submitted: 26/12/2019; Accepted:23/04/2020

Amata Mwalo Mathias, PhD Student. (Corresponding Author). Maseno University, Tel. +254 711673 984. P.O. Box 3848 - 40100 Kisumu, Kenya. Email: amatamwalo2014@yahoo.com

Tom Olielo, PhD. Maseno University. Tel. No. +254 720349 550. P.O. Box Private Bag, Maseno, Kenya.Email: olielotom@gmail.com

Destaigns N. Nyongesa, PhD. Dean School of Business and Economics, Maseno University, Kenya. Tel.+254 721218992 Email: destaingsnyongesa@gmail.com 


\section{Introduction}

According to the United Nation Commission on Trade and Development (UNCTAD, 2009), the maturity of tourism service coupled with size and breath of domestic economy influences the beneficial tourism linkages with local enterprises. Backward linkage is the demand connection formed between a given enterprise with other enterprises in the resource market (Battat et al, 1996; Frank et al., 1999). Backward linkage is measured as proportion of total raw material and components sourced locally per year (Loughlin, 1981; McAleese \& McDonald, 1978 \& O`Farrel, 1981). Tourism backward linkage is, thus, an empirical indication of relative importance of tourism to the local economy (Mak, 2004).

Though, according to United Nations Environmental Program (UNEP, 2011), proportion of tourists spending in local economy coupled with indirect economic activities induced by tourists` spending determine local economic effects of tourism, economic impact of tourism on the economies of almost all countries of Sub Saharan Africa has not been optimal (UNCTAD, 2017). In Kenya, only between $2 \%$ and $5 \%$ of total tourism receipt cascade down to local people at the grass root level in form of low income jobs and income from sale of agricultural products and souvenir (Akama, 1997; Bachmann, 1988). Also, according to a World Bank report titled 'Kenya Country Economic Memorandum: From Economic Growth and Shared Prosperity' published in 2016 by the World Bank Group, the country's economic growth which accelerated in the past decade has not resulted in widespread prosperity for all Kenyans. According to the report, Kenya`s economy still remained amongst the poorest $25 \%$ of countries in the world with poverty level as high as $40 \%$ of the population (World Bank, 2016). It is no wonder that Akama (2000) and Dieke (1991) down played the role of Kenya's tourism in the long term sustainable economic growth of the country.

Fortunately, micro and small enterprise sector is the fastest growing in Kenya with $66 \%$ of 1.3 million enterprises located in rural areas (Ministry of Industrialization and Vision 2030, 2002). The sector has been recognized in the Kenya Sector Plan for Tourism 2013 -2017 as central in sustainable tourism development (Ministry of Devolution and Planning, 2013). However, the development and mainstreaming of micro and small enterprise sector into the national economy has been hampered by such structural factors as unfavorable policy environment and taxation regime, inhibitive legal and regulatory environment, limited access to information, market and financial services, inadequate business skills and access to technology, limited access to infrastructure, formal and informal entry barriers, HIV/AIDS, and limited access and lack of adherence to health and safety in work places (Ministry of Labor and Human Resource Development, 2005). Despite the structural weaknesses in the sector generally, tourism enterprises are indispensable in the prosperity of a destination as they enhance trickle-down effect of tourists` spending into local economy (Ateljic \& Page, 2009).

Kisumu as one of the 47 Counties of Kenya has a growing youthful population majority of whom are unemployed, without entrepreneurial skill and who have been identified in the County Integrated Development Plan 2013 - 2017 as a threat to development (Ministry of East Africa Affairs, Commerce and Tourism, 2013). However, according to Sector Plan for Tourism $2013-2017$ involvement of the youth in tourism activities at County level economically empower them and help reduce insecurity. But the ability of Kisumu County hospitality industry to absorb unemployed youth has been undermined by its very low occupancy rate (Kenya National Bureau of Standards (KNBS, 2013). Therefore, limited penetration of tourism activities and skills in Kisumu County created insignificant backward linkage with local micro and small enterprises which in turn denies local business people opportunities for appropriating optimal economic benefits from tourism. The purpose of this study was to establish the moderating effect of level of tourism business networks on the relationship between physical location of tourism firms, type of tourism firms and proportion of purchase from local micro and small enterprises by tourism enterprises. The hypothesis 
behind the study was that the influence of location and type of tourism firm on proportion of local purchase is independent on the extent of business networks in tourism.

\section{Literature Review}

Business networks are independent enterprises bound together by trust or some common interest, and which are useful in not only transferring knowledge, as conduit for information, and diffusion of intensive skills that are costly to secure, but also provide opportunities for exchanging goods and services that are not easy to enforce through contractual arrangement (Hisrich, 2008). Networks are thus, "the framework of individual and organization relationships which form the stage upon which entrepreneurial performance is played" (Wickham, 1998:169). Every business is found in a network of relationship with other enterprises which is either tight or loose network (Wickham, 2006). In tourism, according to Baggio et al. (2008), business networks are more critical than in any other industry.

Criticality of business network in tourism was supported by a study conducted by Bickerdyke (1996) in Australia, where it was established that tourism had the most inter organization networks. Businesses with international or regional associations tended to have impressive performance owed to its enhanced ability to attract business worldwide (Sudhir, 2009). For example, Sudhir established that airlines which developed working relationship with hotel referrals improved their payload significantly. Cai and Szedl (2016) conducted a field experiment wherein they sought to establish inter - firm relationship and business performance in China. The study, which was based on random sample of 2800 young Chinese managers, was conducted in Nanchang. The finding of this study was that business networks positively correlated with firm performance through such mechanisms as peer effect, trust, improved access to business partners and information diffusion. Based on this finding, they underscoring the importance of policy of organizing business associations in the development of private sector. However, this study was neither based on managers working in tourist industry nor on the moderating effect of business network on tourism backward linkage with local business which this study seeks to establish. Further, due to different structural settings and institutional arrangements between Nanchang and Kisumu County, it is highly doubtful whether the findings could apply to Kisumu County.

In yet another study done in Lagos Nigeria, Igwe and Minai (2011) wanted to find out the effect of location on performance of small firms. From the physical geography perspective, location of a feature can be established as either absolute or relative location by use of coordinate system or reference to something else respectively (Gabler et al., 2007). In this context, location means relative location. Igwe and Minai used a cross sectional study based on questionnaire survey approach. They adopted a systematic random sampling of 300 entrepreneurs and owner managers who were registered with state government of Lagos. In the end, they found out that location had a moderating effect on the relationship between external factors, individual and firm characteristics with firm performance. The finding was in conformity with the urban economic theory in which key locations such as proximity to airport, urban centers and seafronts confer higher turnover and profit (Sinclair \& Stabler, 1997). It was also consistent with perspective of Zimmerer (2005) that location significantly and positively affects the relationships, and that choosing a location which is convenient to target customers enhances growth rates and success of enterprises. Further, business location decision was influenced by proximity to raw material, business premise accessibility, quality of road network and level of economic activity in an area (Minai, 2011). The conclusion from the study was that location was a significant consideration in entrepreneurship development. However, according to their own admission, their finding was biased against trade and distribution sector. Trade and distribution services spans tourist industry and thus, leaving them out in the study discounts applicability of findings in tourism business. Also, whereas this finding was about the moderating effect of location in influencing business performance, 
the current study, on the contrary, seeks to establish the moderating effect of business networks on the relationship between location and backward linkage. Therefore, the moderating effect of business network on the relationship between location and backward linkage has not been established but the current study seeks to find it out.

Khanal et al. (2014) carried out a study on tourism inter - sector linkage in Lao PDR economy. The study used international visitors` expenditure survey, and was based on input output model. It was established that between 2003 and 2008 tourism depended heavily on such sectors as food and beverage, manufacturing, wholesale and retail trade, agriculture and livestock. A similar study conducted in Tanzania by Kweka et al. (2001) found out that food and beverage, fishing, staple food, whole and retail trade were most important sectors for tourism. However, another study carried out by Yobesia and Valle (2009) on the economic contribution of tourism on Kenya's economy established that tourism had weak backward linkage with extractive activities in which most people were employed. The conclusion from Yobesia and Valle finding was that the real economic impact of tourism on local economy was weak.

From the literature, it is apparent that tourism is significantly linked with sectors of the economy such as food and beverage, wholesale and retail trade, but poorly linked with a section of the economy biased towards extractive industry. However, types of tourism enterprises that have linkages with the identified local sectors are not only unclear but also the extent to which tourism is linked with non-extractive activities within Kisumu County is not yet established. Also, the input - output model in the analysis has drawbacks as it has been found to require much data and time to construct as compared with multiplier approach which is cheaper and efficient (Jenkins \& Likorish,1997). In contrast, this study will not only establish the moderating effect of business network on the relationship between type of tourism firms and backward linkage but also identify the tourism firms themselves which have such significant backward linkage with general local economy.

\section{Methodology}

\subsection{Sampling and Data Collection}

Cross section survey was adopted in the study, wherein target population of 266 Tourism enterprises operating in Kisumu County was used. The enterprises consisted of of hotels, lodges, guest houses, restaurants and clubs. From the target population, a stratified random sample of 106 was drawn based of Fisher Formulae. Permission for conducting research in Kisumu County was sought and granted from National Commission on Science Technology and Innovation, Kisumu County Commissioner and County Director of Education. Authorization documents were attached to the self-administered questionnaires which were distributed to the 106 Tourism Enterprises. Quantitative data were collected from the enterprises. From Table 1, the population size for the three categories of enterprises and their corresponding sample sizes drawn based on a multiplier of 0.3985 is indicated. The overall sample size of 106 enterprises was drawn, consistent with 0.075 margin of error with $95 \%$ confidence interval. The sample size was comprised of three sub groups of different sizes as shown in the Table 1.

Table1: The Categories and Sample Sizes of Tourism Enterprises.

\begin{tabular}{|c|c|c|c|c|c|}
\hline $\begin{array}{l}\text { CATEGORIES } \\
\text { ENTERPRISES }\end{array}$ & $\mathbf{O F}$ & TOURISM & POPULATION & MULTIPLIER & SAMPLE \\
\hline \multirow{2}{*}{\multicolumn{2}{|c|}{ Hotels, Motels and Lodges }} & & SIZE & & SIZE \\
\hline & & & 128 & 0.3985 & 51 \\
\hline
\end{tabular}




\begin{tabular}{lccc} 
Guest Houses & $\mathbf{7 0}$ & 0.3985 & 28 \\
Restaurants & $\mathbf{6 8}$ & 0.3985 & 27 \\
\hline TOTAL & $\mathbf{2 6 6}$ & 0.3985 & 106 \\
\hline \hline
\end{tabular}

\section{Results}

\subsection{Effect of Between-Subject Factors}

The objective was to establish the moderating effect of tourism business networks on the relationship between physical location, type of tourism enterprises and local purchase ratio. In order to achieve the foregoing objective, ANOVA based on Generalized Linear Model, was adopted. The model is formulated below as; Local Purchase Ratio = Baseline + Location effect + Tourism Type Effect + Location*Tourism Type Interaction Effect + Tourism Business Network Effect + Location *TB Network Interaction Effect + Tourism Type*TB Network Interaction Effect + Location*Tourism Type $*$ TB Network Effect + Within Group Error .

Local purchase ratio was used as the continuous dependent variable. The Between-Subject Factors included physical location factor measured at three levels namely, outskirts of Kisumu Town, within Kisumu CBD, and rural areas of Kisumu County. Type of tourism enterprise factor was measured at three levels namely hotels and lodges, guest houses, restaurants and clubs. Lastly, level of tourism business network factor was measured at two levels namely, 2 and less networks, and 3 and more networks. The measurement levels for the three factors and their respective group sizes are shown in Table 2 below.

Table 2: Levels and Group Sizes of Between-Subjects Factors.

\begin{tabular}{llll} 
Factors & Levels & Value Label & Group Size \\
\hline Level of & 1 & & \\
Networking & 2 & 2 and less networks & 42 \\
Enterprise & 1 & Oand more networks & 64 \\
Location & 2 & Within Kisumu CBD & 53 \\
& 3 & Rural areas within Kisumu & 31 \\
Enterprise & 1 & Hotel \& lodge & 22 \\
Type & 2 & Guest house & 51 \\
& 3 & Restaurant \& club & 28 \\
\hline \hline
\end{tabular}

\subsection{The Main and Interacting Effects of the Factors}

From the Table 3, the moderating effect of tourism business network on the relationship between location of tourism business and local purchase ratio is significant ( $F$ value $=6.337$, $\mathrm{p}$ value $=0.003)$. However, there is no significant interaction effect between level of tourism business network and type of tourism enterprise $(\mathrm{F}$-value $=1.863, \mathrm{p}$ value $=0.161)$. Generally, however, the effect of type of tourism enterprise on the local purchase ratio does 
not depend on the level of business networks developed by tourism businesses. Also, the main effect of type of tourism enterprises on local purchase ratio is insignificant ( $F$ value $=0.103, p$ value $=0.902$ ). Therefore, the hypothesis that the influence of location and type of tourism firm on proportion of local purchase is independent on the level of business networks in tourism is partly rejected.

Table 3: Test of Between-Subject Effects.

\begin{tabular}{|c|c|c|c|c|c|}
\hline \multicolumn{6}{|c|}{ Dependent Variable: Local Purchase Ratio } \\
\hline Source & $\begin{array}{l}\text { Type III Sum of } \\
\text { Squares }\end{array}$ & Df & $\begin{array}{l}\text { Mean } \\
\text { Square }\end{array}$ & $\mathrm{F}$ & Sig. \\
\hline Corrected Model & $2.102^{\mathrm{a}}$ & 16 & .131 & 1.721 & .057 \\
\hline Intercept & 27.185 & 1 & 27.185 & 356.185 & .000 \\
\hline Network Factor & .394 & 1 & .394 & 5.163 & .025 \\
\hline Location & .494 & 2 & .247 & 3.236 & .044 \\
\hline Enterprise Type & .016 & 2 & .008 & .103 & .902 \\
\hline $\begin{array}{l}\text { Network Factor } * \\
\text { Location }\end{array}$ & .967 & 2 & .484 & 6.337 & .003 \\
\hline $\begin{array}{l}\text { Network Factor * } \\
\text { Enterprise Type }\end{array}$ & .284 & 2 & .142 & 1.863 & .161 \\
\hline $\begin{array}{l}\text { Location * Enterprise } \\
\text { Type }\end{array}$ & .090 & 4 & .022 & .294 & .881 \\
\hline $\begin{array}{l}\text { Network Factor * } \\
\text { Location * Enterprise }\end{array}$ & .277 & 3 & .092 & 1.210 & .311 \\
\hline Error & 6.793 & 89 & .076 & & \\
\hline Total & 56.521 & 106 & & & \\
\hline Corrected Total & 8.894 & 105 & & & \\
\hline
\end{tabular}

\subsection{Effect of Location of Tourism Enterprises and Level of Business Networking}

According to result in Table 4, tourism enterprises with two and less business networks, and located in the outskirts of Kisumu City, Kisumu Central Business District (CBD) and rural areas have, on average, $62 \%, 83 \%$ and $78 \%$ respectively of their total purchases sourced from local suppliers. Also, as indicated in Figureland Table 4, the moderating effect of tourism business network is positive in both rural areas and in the outskirts of Kisumu Town, but it is negative in Central Business District. Further, the moderating effect of tourism business networks is more negatively stronger in Kisumu Central Business District than it is positively stronger in rural and outskirts of Kisumu Town. Further, similar tourism enterprises located in the outskirts of Kisumu City, Kisumu CBD and rural areas of Kisumu County, but with three and more business networks get, on average, $67 \%, 33 \%$ and $79 \%$ of their total input purchases from local businesses. From the result, it is apparent that tourism enterprises located in outskirts of Kisumu City and rural areas with three and more business networks outperform their counterparts with two and less business networks in creating linkages with local economy. However, tourism enterprises with two and less business networks outperform those with three and more business networks in creating local economic linkages in Kisumu CBD. 
Table 4: Marginal Mean and Variability in Local Purchase Ratio.

Level of Networking Enterprise Location Mean Std. Error $\quad 95 \%$ Confidence Interval

\begin{tabular}{|c|c|c|c|c|c|}
\hline & & & & $\begin{array}{l}\text { Lower } \\
\text { Bound }\end{array}$ & $\begin{array}{l}\text { Upper } \\
\text { Bound }\end{array}$ \\
\hline \multirow[t]{3}{*}{2 and less Networks } & $\begin{array}{l}\text { Outskirt of Kisumu } \\
\text { Town }\end{array}$ & .618 & .064 & .490 & .745 \\
\hline & $\begin{array}{l}\text { Within Kisumu } \\
\text { CBD }\end{array}$ & .831 & .078 & .677 & .985 \\
\hline & $\begin{array}{l}\text { Rural Areas within } \\
\text { Kisumu }\end{array}$ & $.781^{\mathrm{a}}$ & .120 & .544 & 1.019 \\
\hline \multirow[t]{3}{*}{3 and more Networks } & $\begin{array}{l}\text { Outskirt of Kisumu } \\
\text { Town }\end{array}$ & .673 & .073 & .527 & .818 \\
\hline & $\begin{array}{l}\text { Within Kisumu } \\
\text { CBD }\end{array}$ & .326 & .107 & .114 & .538 \\
\hline & $\begin{array}{l}\text { Rural Areas within } \\
\text { Kisumu }\end{array}$ & .793 & .074 & .646 & .939 \\
\hline
\end{tabular}

a. Based on modified population marginal mean.

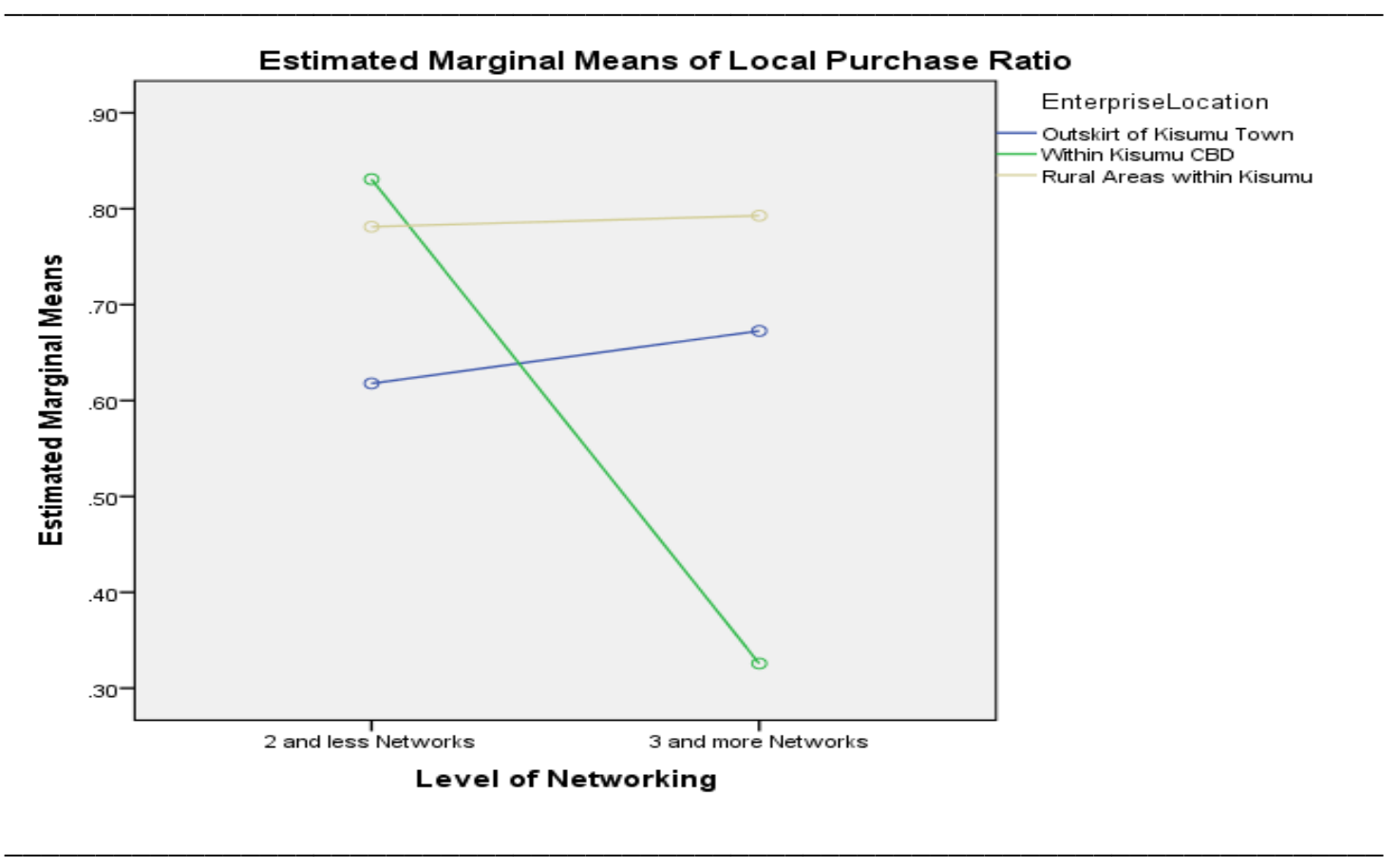

Figure 1: Moderating Effect of Tourism Business Networks. 


\section{Conclusion, Implications and Limitations}

The moderating effect of tourism business networks on relationship between physical location of tourism enterprises and local purchase ratio was found to be significantly positive in rural areas and outskirts of Kisumu City but significantly negative in Central Business District. But from the previous findings of Cai and Szedl (2016), business networks was found to be positively correlated with firm performance and the performance was moderated by location (Igwe \& Minai, 2011). However, when firm performance is interpreted to mean the extent to which the firm creates linkage with local enterprises, then current finding is partly consistent with that of Cai and Szedl with regards to tourism enterprises in rural and outskirts of Kisumu County, but partly inconsistent with regards to tourism enterprises in Central Business District of Kisumu County. Further, the current findings differ from that of Igwe and Minai as the study focused on moderating effect of tourism business networks on the relationship between physical location and firm performance. Therefore, on the basis of the finding, the contribution of the current study is the revelation that the effect of business network on firm performance is not only positive but it can also be negative, and it varies with the location of tourism enterprises. The current study also deviates from previous studies of Wickham (2006), Bickydyke(1996) and Baggio et al. (2008) in that it has established the strength and directional of the interaction effect of business networks on the relationship between enterprise physical location, and extent of tourism backward linkage with Kisumu County's economy. The moderating effect of tourism business networks has been established to be strongest but negative in Kisumu Central Business District, but positively more stronger in the outskirts of Kisumu City than it is in rural areas of Kisumu County.

The implication is that tourism enterprises, in extensive business network and located in rural areas and outskirt of Kisumu Town, tended to purchase more inputs from local suppliers than from suppliers based outside Kisumu County. On the contrary, tourism enterprises with extensive business networks which are located in Kisumu Central Business District, generally tended to purchase more inputs from suppliers based outside of Kisumu County than those based within. In order for increase in business network developed by tourism enterprises within the County to have positive effect on tourism backward linkage with local economy, such networks amongst tourism enterprises in rural and outskirts of Kisumu County were most likely developed with other local businesses both in tourist industry and outside the industry. Therefore, expansive business networks amongst tourism enterprises, based in rural areas and areas peripheral to the City, are likely to boost local industrialization which can help alleviate poverty in rural areas. Most tourism businesses located in Central Business District are, generally, large enterprises owned by businessmen who are not residents of Kisumu County. Such businesses rely on resource markets external to Kisumu County. Thus, expansive business networks amongst tourism enterprises located in central business district or urban areas lead to increased income leakages causing low level of local industrialization unless county government initiate structural adjustment in the local economy geared towards improving local production, and making such local output more attractive to city-based tourism enterprises than those from resource markets external to the County`s economy. Therefore, it seems that collaborative strategies amongst Tourism Enterprises in rural areas can invigorate local economy than competition amongst them, while increased competition amongst tourism enterprises in Kisumu Central Business District, as opposed to cooperation, is healthy for the local economy and suppliers.

As a limitation, the finding from the study does not provide general picture of the general economic relationship between tourism enterprises and local micro and small businesses in Kenya. The sample drawn from tourism enterprises located only in Kisumu County and thus cannot be generalized to all tourism enterprises in Kenya. Secondly, owners of local micro and small businesses within Kisumu County were not directly involved in the study. Data 
pertaining local owners of micro and small enterprises was obtained from tourism enterprises to which they supplied inputs.

\section{References}

Akama, J. (1997). Tourism Development in Kenya: Problem and Policy Alternatives. Progress in Tourism and Hospitality Research 3, 95-105.

Akama, J. (2000). The effecacy of tourism as a tool for economic development in Kenya. Burja(eds) Development Policy Management in Sub Saharan Africa: Tourism and African Development - Trends and Critical Issues. DPML Bulletin 7(1). Addis Ababa: Commercial Printing Enterprise.

Ateljevic, J., \& Page, J. (2009). Tourism and Entrepreneurship International Perspectives. USA: Elservier Ltd.

Bachamann, P. (1988). Tourism in Kenya: Abasic need for whom? Bern: Peter Long.

Baggio, R., Cooper, C., \& Scott, N. (2008). Network Analysis and Tourism: From Theory to Practice. Cleveton: Channel View.

Battat, J., Frank, I., \& Shen, X. (1996). Foreign Investment Avisory paper 6 on Supplier to Multinational: Linking Program to strengthen local companies ni Developing Countries. Washington D.C: International Finance Cooperation and the World Bank.

Becken, S., Gan, C., \& Khanal, B. (2014). Tourism inter-industry linkage in the Lao PDR economy: an input - output Analysis. Tourism Economics, 20(1), 171-194.

Bickerdyke, I. (1996). Australia: The evolving Structure and Strategies of Business Networks. (OECD, Ed.) Network andLocal Development: Competing and Coo[erating in Local Productive Systems, 203-206.

Blake, Kweka, J., A., \& Morrissey, O. (2001). Is Tourism a key sector in Tanzania? Input Output Analysis of Income, Output, Employment and Tax Revenue. Nottingham: Christel Dehaan Tourism and Travel Research Institute.

Cai, J., \& Szedl, A. (2016). Interfirm Relationship and Business Performance. Central Europe: CEPR.

Communication, Economic Planning and Development Executive Committee (2013). Kisumu County First County Integrated Development Plan 2013 -2017. Kisumu: Kisumu County Government.

Dieke, P. (1991). Policies for Tourism Development in Kenya. Annals of Tourism Research, 1(9), 69-90.

Frank, L., Guinereas, Heifner, \& Paulo, P. (1999). Backward and forward Linkages in Manufacturing Location Decisions. North America Regional Science Association. North Orleans: North America Regional Science Association International Meeting.

Gabler, E., Petersen, F., \& Trapasso, M. (2007). Essentials of physical Geography 8th Edition. Belmont, USA: Thomson Corporation.

Hisrich, D. R. ( 2008 ). Entrepreneurship. New York: McGraw - Hill/Arwin.

Igwe, E., \& Minai, M. (2011). Conceptual framework of the effect of location on performance of small firms. Asian Social Science, 7(12).

Jenkins, C., \& Likorish, J. (1997). An Introduction to Tourism. Oxford: Butterworth Heineman.

Keena, A., \& Steven, P. (2016). Applied Multivariate Statistics for the Social Sciences. New York: Routledge.

KNSB(Kenya Nationa Bureau of Standards),(2013). Exploring Kenya s Inequality: Pooling Apart or Pooling together? Nairobi: Kenya National Bureau of Statistics

Mak, J. (2004 ). Tourism and the Economy, Understanding the Economics of Tourism. . Honolulu: University of Hawaii Press.

Ministry of Devolution and Planning. (2013). Kenya Sector Plan for Tourism 2013 - 2017. Nairobi: Government of Kenya. 
Ministry of East Africa Affairs, Commerce and Tourism. (2013). Sector Plan For Tourism 2013 - 2017. Nairobi: Government of Kenya.

Ministry of Industrialization and Vision 2030. ( 2002 ). Economic Recovery Strategy for Wealth and Employment Creation 2003 - 2007. Nairobi: Government of Kenya.

Ministry of Labour and Human Resources Development. (2005). Sessional paper No. 2 on Development of Micro and Small Enterprises for Wealth and Employment creation for poverty reduction. Nairobi: Government of Kenya.

O`Farrell, P., \& O`Loughlin. (1980). An analysis of Industry Linkages in Ireland. Durban: Industrial Development Authority.

Scarborough, M., \& Zimmerer, T. (2005). Essentials of Entrepreneurship and small business Management. New Delhi: Prentice - Hall.

Sinclair, T. (1990). Tourism Development in Kenya. . Washington, D.C: World Bank.

Sinclair, T., \& Stabler, M. (1997). The Economics of Tourism. USA and Canada: Routledge.

Sudhir, A. ( 2009). Hotel Front Office: A training Manual. New Dhelhi: Tata McGraw Hill Education Private Ltd.

United Nation Conference on Trade and Development. (2009). FDI in Tourism: The Development Dimension, United Nations, Geneva.

United Nations Conference on Trade and Development. (2017). Beyond Austerity: Towards Global New Deal, United Nations, Geneva.

United Nations Environmental Program. (2011). Emerging issues in Global Environment, United Nations, Geneva.

Valle, E., \& Yobesia, N. (2009). Economic contribution of tourism in Kenya. Tourism Analysis, 14, 4001-414.

Wickham, P. (2006). Strategic Entrepreneurship, Fourth Edition. England: Pearson Limited Company.

World Bank, (2016). The World Bank Annual Report 2016. Washington DC. World Bank.

\section{Author Biography}

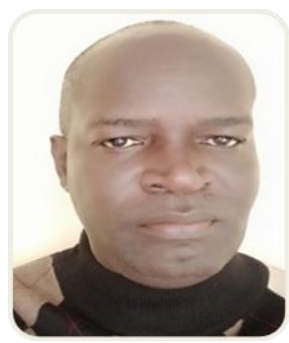

Mr. Amata Mwalo Mathias holds a Master of Science Degree in entrepreneurship from Jomo Kenyatta University of Agriculture and Technology, a Bachelor of Science degree in tourism of Moi University and a Post Graduate Diploma in Education of the University of Nairobi. Currently, he is pursueing a PhD in Tourism Management at Maseno University in Kenya. Amata has taught tourism and entrepreneurship in a number of middle level colleges in Kenya, including Momaba Technical Training Institute between 2001 and 2004, Centre for Tourism Training and Research between 2004 and 2011 and Kenya Polytechnic. He has successfully served as a tutorial fellow at Great Lakes University of Kisumu between 2016 and 2019. He is, currently, serving as a part time lecturer in the department of tourism at Jaramogi Oginga Odinga University of Science and Technology in Siaya, Kenya. 
Dr.Tom Olielo is currently a lecturer in the department of Eco tourism, Hotel and Institutional Management within the School of Business and Economics, Maseno University - Kenya. Olielo holds a PhD in Foods, Nutrition and Dietetics of Kenyatta University. He also, has a Master Degree in Food Science \& Food Technology of Nairobi University.



Dr. Destaigns N. Nyongesa is the Dean, School of Business and Economics, Maseno University. He holds a PhD and Master Degrees in Economics of Maseno University, Kenya. Formally, he was the Chairman, Department of Economics of Maseno University. 